\title{
ŚWIĘTOŚĆ W CZASACH PODBOJÓW ISLAMSKICH. MĘCZENNICY CHRZEŚCIJAŃSCY Z GAZY Z VII WIEKU
}

Pobożność chrześcijańska nieustannie przywoływała przykład nieustraszonych wyznawców wiary w Chrystusa. Świadectwo męczenników przyczyniało się do przypomnienia wspólnocie kościelnej konieczności wierności, ofiary i świadectwa prawdzie Ewangelii, czego niejednokrotnie wymagały okoliczności historyczne. W VII w., gdy Arabowie rozpoczęli falę podbojów, obejmujących swoim zasięgiem wschodnie i południowe wybrzeże Morza Śródziemnego, okazało się, że imperium bizantyjskie w tamtym regionie nie było w stanie oprzeć się nowym najeźdźcom. To, co początkowo mogło uchodzić wyłącznie za wyprawy rabunkowe, zamieniło się w wojnę zaborczą. W tym kontekście historycznym należy analizować męczeńską śmierć sześćdziesięciu żołnierzy chrześcijańskich z terytorium Gazy. Wydarzenia te opisują dwie wersje łacińskich tłumaczeń ich Passio. Pozbawiony upiększeń opis wskazuje na najwyższą formę wierności Chrystusowi ze strony zwykłych chrześcijan, pełniących służbę w oddziałach wojskowych. Historia męczenników z Gazy pokazuje, iż nie istniała wspólnota wiary z muzułmanami lub kompromisy wierzących szczerze w Chrystusa z nową władzą polityczno-religijną. Odstępstwo żołnierzy z pewnością podkopałoby morale mieszkańców podbijanej Palestyny i zaszkodziłoby powszechnie uznanemu autorytetowi Kościoła. Uważa się powszechnie, że wczesny islam cechował duch tolerancji i silne poczucie sprawiedliwości. Jeśli to prawda, to uzasadnienie można znaleźć w dążeniu Arabów do wykorzystania zdobyczy cywilizacyjnych i wyższej kultury podbitych ludów. Kto z chrześcijan chciał zachować swoją pozycję, musiał dostosować się do zasad islamu i przyjąć przesłanie Mahometa. Męczeństwo bizantyjskich żołnierzy stanowiło jeden z elementów ostatnich akordów chrześcijańskich dziejów Palestyny. Od zamysłu hagiografa daleka była idea głoszenia, że islam to religia pokoju. Przyświecała mu raczej myśl o męczennikach jako milites Christi ${ }^{1}$. Sam fakt zachowania się aż dwóch

${ }^{*}$ Dr hab. Mieczysław Celestyn Paczkowski OFM, prof. UMK - profesor nadzwyczajny w Katedrze Historii Kościoła i Patrologii na Wydziale Teologicznym Uniwersytetu Mikołaja Kopernikaw Toruniu; e-mail: celestyn@umk.pl.

${ }^{1}$ Już dla Tertuliana (De fuga mundi 1, 5; Ad martyras 3, 3) męczennicy byli prawdziwymi żołnierzami Chrystusa, a ich wytrwałość Afrykańczyk opisywał jako walkę. Cyprian z Kartaginy nawiązał do tej idei ukazując życie chrześcijańskie jako nieustanne zmaganie się z prześladowania- 
tłumaczeń łacińskich Passio, wskazuje na zainteresowanie chrześcijan z Italii losem wspólnot ich braci na Wschodzie.

1. Chrześcijańska Gaza i najazd islamski. Leżące na pograniczu egipsko - palestyńskim miasto Gaza² ustępowało znaczeniem innym miejscom związanym z historią biblijną Starego i Nowego Testamentủ ${ }^{3}$ Jednakże miejscowość ta $\mathrm{w}$ epoce późnoantycznej miała wiele atutów. Była usytuowana w bardzo dogodnej pozycji geograficznej pomiędzy brzegiem Morza Śródziemnego, a krańcem Pustyni Negew ${ }^{4}$, na szlaku łączącym kontynenty Azji i Afryki, wiodącym przede wszystkim do Aleksandrii w Egipcie. Należy odróżnić miasto Gazę ${ }^{5}$ od jego portu, zwanego Maiuma (dzisiejsza El-Mine) ${ }^{6}$. W części portowej miasta chrześcijaństwo przyjęło się bardzo szybko, a Ewangelia Jezusa Chrystusa dotarła tam jeszcze w czasach apostolskich. W samej Gazie kulty pogańskie przez długi czas miały jednak mocną pozycję ${ }^{7}$. Dopiero na początku V w. za czasów Porfiriusza, najpierw biskupa Maiumy, a później Gazy (395-420), cesarz Arkadiusz zakazał w Gazie kultu pogańskiego ${ }^{8}$.

mi i przeciwnościami. Wśród cech miles Christi biskup Kartaginy wymieniał niezwyciężoną siłę wiary, niezachwianą ufność w Bożą pomoc i przyjęcie ofiary przez Boga (por. Cyprianus, Epistula 10 i 58). Moralia Grzegorza Wielkiego obfitują w liczne porównania i terminologię odnoszącą się do duchowej walki i zmagań „Bożego żołnierza”. Por. E. Herràn Alonso, La configuración literaria del tópico del ,,miles Christi” entre l'Edad Media y el Renacimiento, w: Actes del X Congrés Internacional de l'Associación Hispànica de Literatura Medieval (Alacant, 16-20 setembre 2003), ed. R. Alemany - J.L. Martosi - J.M. Manzanaro, Alacant 2005, 880-881.

${ }^{2}$ Odnośnie do syntetycznej historii tego miasta por. M.A. Meyer, History of the City of Gaza. From the Earliest Times to the Present Day, Columbia University Oriental Studies 5, New York 1907.

${ }^{3} \mathrm{Z}$ terenami Gazy związana jest biblijna historia Samsona (por. Sdz 16). Teksty prorockie wspominają o wrogiej względem Hebrajczyków postawie mieszkańców Gazy zamieszkałej przez Filistynów (por. Am 1, 6).

${ }^{4} \mathrm{Na}$ temat położenia Gazy por. L. Di Segni, The Territory of Gaza: Notes of Historical Geography, w: Christian Gaza in Late Antiquity, ed. B. Bitton-Ashkelony - A. Kofsky, Jerusalem Studies in Religion and Culture 3, Leiden 2004, 41-60.

${ }^{5}$ Gazę wzmiankują: Eusebius Caesarensis, Onomasticon 62, 22-26 (według thumaczenia św. Hieronima: 63, 16-23); Anonimus Piacentinus, Itinerarium 33; Hierocles, Synecdemos 721, 1-11. Miasto to przedstawiają także mozaiki z terytorium Jordanii: Ma’in, kościół na akropolu (VIII w.) i Umm ar-Rasas - kościół św. Szczepana.

${ }^{6}$ Według wielu tekstów Maiuma to „targowisko Gazy”. Św. Hieronim relacjonuje, że wielki inicjator monastycyzmu w Palestynie - Hilarion „uzbrojony w Chrystusa, wkroczył na pustynię, która rozciaga się wzdłuż wybrzeża o siedem mil od Maiumy, targowiska Gazy" (Hieronymus, Vita S. Hilarionis 3, 7, PL 23, 30C, thum. B. Degórski: Św. Hieronim, Żywot Hilariona, w: Św. Hieronim, Żywoty mnichów Pawła, Malchusa i Hilariona, ŹM 10, Kraków 1995, 120).

${ }^{7}$ Dominował kult pogański Marnasa, bożka deszczu, którego podobizna była bita na ówczesnych monetach. Ludność uczestniczyła w świętach pogańskich jeszcze długo po chrystianizacji tego terenu. Por. N. Belayhe, Pagan Festivals in Fourth-Century Gaza, w: Christian Gaza, s. 5-22.

${ }^{8} \mathrm{~W}$ czasie zamieszek świątynia Marnasa została zburzona, a jej marmurami na znak pogardy wyłożono place i ulice miasta. Na miejscu zburzonej świątyni rzymskiej zbudowano kościół na planie krzyża. 
Jedną z największych postaci z okolic Gazy był św. pustelnik Hilarion', którego ascetyczne życie znamy z wnikliwej i przenikniętej podziwem dla jego świętości biografii napisanej przez św. Hieronima ${ }^{10}$. Strydończyk tworzy swoisty paralelizm pomiędzy Hilarionem a jego mistrzem - Antonim Egipskim, inicjatorem życia monastycznego ${ }^{11}$. Należy zaznaczyć, że wiele z Apoftegmatów pochodzi z okolic Gazy. Do innych sławniejszych mnichów z pogranicza palestyńsko-egipskiego należeli: Barsanufiusz ${ }^{12}, \operatorname{Jan}^{13}$ i Doroteusz z Gazy, którzy pozostawili cenne pisma ascetyczne. Reprezentatywna jest również tajemnicza postać Izajasza z Gazy. Zbiór jego nauk to pierwszy produkt myśli monastycyzmu palestyńskiego, połączonego ściśle z duchowością Ojców egipskich ${ }^{14}$. Ruch monastyczny odcisnął swoje piętno także na hierarchii kościelnej, czego przykładem jest wspomniany Porfiriusz. W okresie soboru w Chalcedonie zjawisko dyskusji teologicznych prowadzonych w kręgach ascetycznych przybierało na sile ${ }^{15}$. Był to zresztą burzliwy okres dla Kościoła, a echa ówczesnych kontrowersji rozbrzmiewały jeszcze w VI wieku ${ }^{16}$. Dramat ówczesnej epoki odzwierciedla biografia Piotra Iberyjskiego ${ }^{17}$, pióra

${ }^{9}$ Urodzony w pogańskiej rodzinie, w Tabatha, $13 \mathrm{~km}$ na południe od Gazy, w 291 r., jako młody chłopiec został wysłany na nauki do Aleksandrii w Egipcie, gdzie poznał chrześcijaństwo, przyjął chrzest i jakiś czas spędził w pustelni św. Antoniego. Z jego błogosławieństwem wrócił do swojej ojczystej ziemi i rozpoczął życie eremity na pustyni w pobliżu rodzinnego miasta. Prześladowania zmusiły go jednak do ucieczki na Cypr, gdzie kontynuował życie pustelnicze. Św. Hilarion jest uważany za pierwszego pustelnika Palestyny, którego wzór życia naśladowało wielu eremitów zamieszkujących górzystą pustynię judzką oraz tereny pustyni Negew. Zmarł w wieku 80 lat w 371 roku. Por. J. Gribomont, Ilarione di Gaza, NDPAC II 2528.

${ }^{10}$ Por. Hieronymus, Vita S. Hilarionis 30, 2, PL 23, 43C, ŹM 10, 149: „Spieszyli do niego biskupi, prezbiterzy, orszaki duchownych i mnichów, a nawet [...] wytworne niewiasty chrześcijańskie, a także ze wszystkich stron z miast i wsi - prosty lud, oraz ludzie dzierżący władzę i sędziowie, aby otrzymać od niego poświęcony chleb lub oliwę".

${ }^{11}$ Por. tamże 14, 11, PL 23, 35A, ŹM 10, 129: „Pan Jezus miał w Egipcie starca; w Palestynie miał młodszego wiekiem Hilariona".

12 Por. D. Hombergen, Barsanuphius and John of Gaza and the Origenist Controversy, w: Christian Gaza, s. 173-182.

${ }^{13}$ Por. L. Perrone, The Necessity of Advice: Spiritual Direction as a School of Christianity in the Correspondence of Barsanuphius and John of Gaza, w: Christian Gaza, s. 131-150.

${ }^{14} \mathrm{Na}$ temat tej postaci por. L. Perrone, La chiesa di Palestina e le controversie cristologiche, Brescia 1980, 286-295.

${ }^{15}$ Por. J.E. Steppa, Heresy and Orthodoxy: The Anti-Chalcedonian Hagiography of John Rufus, w: Christian Gaza, s. 89-106; L. Regnault, Moines et laïcs dans la région de Gaza au VI siècle, w: Christian Gaza, s. 165-172; A. Kofsky, What Happened to the Monophysite Monasticism of Gaza?, w: Christian Gaza, s. 184-194.

${ }^{16}$ Por. G. Downey, Gaza: In the Early Sixth Century, Norman 1963; C.A.M. Glucker, The City of Gaza in the Roman and Byzantine Periods, BAR International Series 325, Oxford 1987.

${ }^{17}$ Znany jako Nabarnugi. Wywieziony jako zakładnik do Konstantynopola, uciekł z niewoli do Jerozolimy, gdzie znalazł schronienie w klasztorze Melanii Młodszej i Geroncjusza. Sam także został mnichem i fundatorem klasztoru gruzińskiego w świętym mieście. Piotr przyjął godność biskupa w Maiumie czyli ośrodku o tendencji monofizyckiej. Por. P. Devos, Pierre l'Ibère, quand 
Jana Rufusa. Napięcia i walki pomiędzy prawowiernymi chrześcijanami i monofizytami stanowiły mało budujący obraz dla postronnych obserwatorów. Był to być może powód długo utrzymującego się w Gazie pogaństwa ${ }^{18}$. Nie brak było pochwał i entuzjazmu dla „pobożnych cesarzy”, do których należał Justynian. Jego dzieło w Palestynie opisał Prokopiusz z Gazy ${ }^{19}$.

$\mathrm{Na}$ pograniczu palestyńsko-egipskim sytuacja uległa zmianie w 614 r., gdy po zwycięstwie nad wojskami bizantyjskimi Palestyna wraz z Jerozolimą zostały opanowane przez Persów pod wodzą Chosroesa. Rozpoczął się okres krwawych prześladowań i barbarzyńskiego palenia świątyń chrześcijańskich $^{20}$. Inwazja sasanidzka spowodowała śmierć tysięcy chrześcijan palestyńskich i niewyobrażalne zniszczenia ${ }^{21}$. Hordy króla Chosroesa II dotarły nawet do najbardziej niedostępnych klasztorów i pustynnych ławr, niemal całkowicie je niszcząc. Wielu mnichów w obawie o swe życie uciekło z klasztorów ${ }^{22}$.

Krótkotrwałe rządy perskie były zaledwie preludium kolejnych nieszczęść w postaci najazdów arabskich, coraz dokuczliwszych i groźniejszych. Muzułmańskie podboje były gwoździem do trumny dla cywilizacji chrześcijańskiej na Bliskim Wschodzie. Obszar od Cezarei Nadmorskiej po Gazę został zdobyty już w 634 roku. Podaje się szacunkową liczbę czterech tysięcy zabitych, przede wszystkim spośród chłopów broniących swojej własności. Unicestwione zostały ośrodki wiejskie w Negewie. Główne miasta Palestyny, jak Jerozolima, Gaza, Jaffa, Cezarea, Nablus czy Scytopolis (Bet Szean), zostały

vint-il à Jérusalem, AnBol 86 (1969) 337-350; M. Starowieyski, Piotr Iberyjski, SWPW 185-186; P. Szczur, Piotr Iberyjczyk, EK XV 677.

18 Por. G. Downey, Paganism and Christianity in Procopius, ChH 18 (1949) 89-102; Y. Ashklanazi, Paganism in Gaza in the Fifth and Sixth Centuries, „Catedra” 60 (1991) 116-122; tenże, Sophists and Priest in Late Antique Gaza According to Chloricius the Rhetor, w: Christian Gaza, s. 195-208.

${ }^{19}$ Najwspanialszym dziełem Justyniana w świętym mieście było wzniesienie nowego kościo-

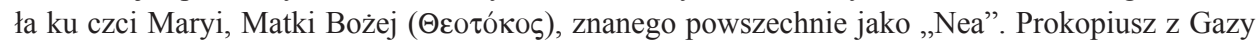
(De aedificiis Justiniani V 6) opisuje w szczegółach tę budowlę.

${ }^{20}$ Według Lekcjonarza Gruzińskiego z VIII w. chrześcijanie mieszkający w świętym mieście gromadzili się w bazylice Zmartwychwstania ('Avó $\sigma \tau \alpha \sigma \iota \varsigma)$, aby wspominać Incendium Hierosolymae czyli zniszczenie miasta przez wojsko króla perskiego Chosroesa II w 614 roku.

${ }^{21}$ Według różnych relacji liczba ta miała wahać się od 66509 do 33 877. Ormiański pisarz Sebeos mówi o 57 tysiącach zabitych i 30 tysiącach uprowadzonych. Relacja Ormianina wspomina także o grzebaniu zmarłych, które odbywało się za aprobatą Persów, którzy wspaniałomyślnie zachęcali do powrotu do normalnego życia, na ile to było możliwe. Por. D.J. Chitty, A pustynia stała się miastem... Wprowadzenie do dziejów monastycyzmu w Egipcie i Palestynie pod panowaniem chrześcijańskim, tłum. T. Lubowiecka, red. nauk. T.M. Gronowski - R. Kosiński, ŹM 45, Kraków - Tyniec 2008, 288.

${ }^{22}$ Tak było w przypadku przyszłego patriarchy z okresu najazdu arabskiego - Sofroniusza, zwanego Sofistą. Opuścił on Palestynę wraz z przyjacielem Janem Moschosem, autorem Pratum spirituale. Por. H. Chadwick, John Moschus and His Friend Sophronius the Sophist, JTS 25 (1974) 41-74. W rzeczywistości Sofroniusz tylko to dziełko rozpowszechnił, por. Sofroniusz z Jerozolimy, SWP 358. 
odizolowane i rozpoczęto ich oblężenie ${ }^{23}$. W tym okresie patriarcha Jerozolimy Sofroniusz (633-638) ${ }^{24}$ w swoim kazaniu na Boże Narodzenie w 634 r. mówił o Arabach, którzy zaatakowali Jerozolimę, okupowali Betlejem i uniemożliwiali dostęp wiernych do kościoła Narodzenia Pańskiego. Dochodziło do rozlewu krwi, burzono kościoły i znieważano krzyże ${ }^{25}$. Katastrofa nastapiła jednak, gdy wojska cesarza Herakliusza zostały rozgromione pod Jarmukiem (20 sierpnia 636). Jerozolima nie mogła liczyć na żadną pomoc. Wtedy patriarcha Sofroniusz postanowił poddać miasto. Warunki poddania Jerozolimy były jednak korzystne i honorowe. Żołnierzom cesarskim pozwolono odejść wolno, a chrześcijanie zachowali swoje kościoły, płacąc jedynie daninę ${ }^{26}$.

Do Ziemi Świętej powrócił pokój. Był on jednak dany przez wyznawców nowej religii - islamu. Uważano często tę religię za herezję wyrosłą na gruncie chrześcijańskim. Opinię tę podzielali również Żydzi, mimo licznych wąt-

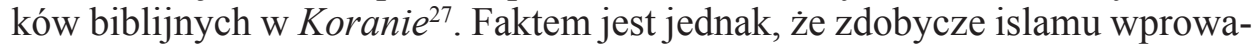
dziły cezurę w ówczesnym międzynarodowym układzie sił. Arabski podbój spowodował ukształtowanie specyficznej pozycji Kościołów Wschodnich ${ }^{28}$, a także wspólnoty chrześcijan palestyńskich. Zdobywcy Bliskiego Wschodu siłą rzeczy skazani zostali na kulturę chrześcijańską. Od chrześcijan Arabowie przejmowali podwaliny filozofii, teologii, historii i sztuki. Arabowie zetknęli się z kulturą przewyższająca ich standardem życia, wiedzy, sztuki i form organizacyjnych religii ${ }^{29}$. Dla Arabów rozpoczął się proces asymilacji kultury

${ }^{23}$ Por. F.M. Abel, Histoire de la Palestine depuis la conquète d'Alexandre jusqu'à l'invasion arabe, t. 2, Études bibliques 1, Paris 1952, 397-399; M. Gil, A History of Palestine, 634-1099, engl. trans. E. Broido, Cambridge - New York 1992, 20 i 169-170; D.J. Constantelos, Christian Hellenism. Essays and Studies in Continuity and Change, New Rochelle 1998, 125-127.

${ }^{24}$ Sofroniusz był znany jako homileta, hagiograf i poeta. Spod jego pióra wyszły hymny na święta kościelne. Przeszedł do historii jako patriarcha jerozolimski z okresu inwazji muzułmańskiej (637). W poetyckich wersach opisuje on wygląd miejsc świętych przed ich zniszczeniem przez Persów w 614 roku. O tym patriarsze wspomina Jan Damasceński w De Imaginibus orationes (I 328; II 344; III 352). Sofroniusz jako jeden z pierwszych dostrzegł niebezpieczeństwo monoteletyzmu, por. P. Verghese, The Monothelite Controversy - A Historical Survey, GOTR 13 (1968) 196-211.

${ }^{25}$ Por. Sophronius Hierosolymitanus, In Christi natalitia, ed. H. Usner, w: tenże, Weihnachtspredigt des Sophronios, „Rheinisches Museum für Philologie. Neue Folge” 41 (1886) 506-507 i 513-515; J.C. Lamoreaux, Early Eastern Christian Responses to Islam, w: Medieval Christian Perceptions of Islam. A Book of Essays, ed. J.V. Tolan, New York - London 1996, 15.

${ }^{26} \mathrm{Na}$ mocy tego porozumienia „niewierni” byli zobowiązani do podporządkowania się tej władzy i płacenia danin (haracz). Danina tylko na początku miała charakter kolektywny i szybko przybrała formę pogłównego (gizyah). Por. A.O. Issa, Les minorites chrétiennes de Palestine à travers les siècles, Jerusalem 1976, 124-125; E. Alschech, Islamic Law, Practice, and Legal Doctrine: Exempting the Poor from the Jizya under the Ayyubids (1171-1250), „Islamic Law and Society” 10 (2003) 348-375; Ch.F. Robinson, Neck-Sealing in Early Islam, „Journal of the Economic and Social History of the Orient" 48 (2005) 401-441.

${ }^{27}$ Por. E. Kopeć, Koran a Biblia, RBL 3 (1952) 263-272.

${ }^{28}$ Por. J.-P. Valognes, Vie et mort des chrètiens d'Orient. Dés origines à nos jours, Paris 1995, 59.

${ }^{29}$ Por. K. Samir, Religion et culture en Proche-Orient arabe, POC 39 (1989) 251-309. 
greckiej i syryjskiej dzięki miejscowym chrześcijanom. To powód, dla którego w pierwszym okresie chrześcijanie cieszyli się względną wolnością, a ich miejsca kultu były szanowane ${ }^{30}$. Patriarcha Sofroniusz, patrząc na arabskich zdobywców, był zaskoczony przede wszystkim ubogim odzieniem i zachowaniem ich przywódcy - kalifa Omara ${ }^{31}$.

2. Dokumentacja hagiograficzna. Okres przejściowy pomiędzy panowaniem bizantyjskim, a podbojem Palestyny przez muzułmanów nie był wolny od gwałtownych wydarzeń i epizodów nietolerancji. Z chwila, gdy zaczęło panować prawo dyktowane przez islamskich zdobywców, nie zabrakło przypadków męczeństwa wśród chrześcijan. Głośnym wydarzeniem była męczeńska śmierć sześćdziesięciu żołnierzy chrześcijańskich w Gazie.

Przypuszcza się, że istniało zaginione dziś tłumaczenie łacińskie integralnej wersji greckiej Passio męczenników z Gazy z wieku VII ${ }^{32}$. Opowiadanie we wcześniejszej wersji zachowało się $\mathrm{w}$ złym pod względem stylistycznym thumaczeniu łacińskim z oryginału greckiego ${ }^{33}$. W redakcji Passio Sanctorum LX Martyrum zwraca uwagę pełen barbaryzmów, toporny styl. Łacińscy mistrzowie pióra $\mathrm{z}$ pewnością ubolewaliby nad nieudolnością $\mathrm{i}$ brakiem obycia językowego u tłumacza. Słownictwo jest ubogie i niezbyt wyrafinowane. Tekst jest pełen ,zapożyczeń i błędnych form”, nie mówiąc o pomyłkach wynikających z winy samego autora. Dochodzą do tego błędy kopisty powodujące trudności w rozumieniu tekstu ${ }^{34}$. Dokument przekazuje niektóre ważne szczegóły techniczne i realia geograficzne, chociaż nie jest zharmonizowany pod względem chronologicznym. Początek dokumentu we wcześniejszej wersji, jak również dalsze jego części, nie wykazują cech konfabulacji w celu upiększenia narracji hagiograficznej. Trudno także szukać śladów skomplikowanych figur retorycznych czy rozwlekłych opisów. W relacji nie pojawia się żadne cudowne wydarzenie ani opisy cudów. Passio jest powściągliwą relacją mocno osadzoną w realiach historycznych. Taki także był prawdopodobnie oryginał grecki.

Passio Sanctorum LX Martyrum znajduje się w manuskrypcie, przechowywanym w Rzymie ${ }^{35}$. To jeden z najstarszych woluminów zawierających

\footnotetext{
${ }^{30}$ Niektórzy myśliciele muzułmańscy uważają, że do wspólnoty wiernych należą także ci, którzy zatrzymują się na pierwszej części wyznania wiary - shachady (żydzi i chrześcijanie).

${ }^{31}$ Miał o nim powiedzieć po grecku do usługującego diakona: „Naprawdę, ten jest obrzydliwością spustoszenia, o której mówił prorok Daniel stojący tutaj, na świętym miejscu” (Theophanes, Chronographia 339, PG 108, 693-694, thum. własne).

${ }^{32}$ Por. D. Woods, The 60 Martyrs of Gaza and the Martyrdom of Bishop Sophronius of Jerusalem, „ARAM - Society for Syro-Mesopotamian Studies Periodical” 15 (2003) 134.

${ }^{33}$ Według BHL 5672m. Dokument jest przechowywany w Watykanie (Arch. Cap. S. Pietro. A. 5 [alias D], 222-223v). Por. Woods, The 60 Martyrs of Gaza, s. 129 i 144-146.

${ }^{34}$ Por. H. Delehaye: Passio Sanctorum Sexaginta Martyrum, AnBol 23 (1904) 289-290.

${ }^{35}$ Por. tamże, s. 289 (tekst s. 300-303). Na temat tego dokumentu por. J. Pargoire, Les LX Soldats Martyrs de Gaza, EO 8 (1905) 40-43; G. Huxley, The Sixty Martyrs of Jerusalem, GRBS 18 (1977)
} 
relacje z męczeństwa poszczególnych świętych. Kodeks datuje się na X lub XI W., a więc na okres względnego spokoju w relacjach Wschód - Zachód, przerwanym epizodem zniszczenia bazyliki Grobu Swiętego w Jerozolimie przez „szalonego kalifa” Hakima i początkiem późniejszych wypraw krzyżowych. Relacja nie jest wyłącznie dokumentem o charakterze hagiograficznym, lecz stanowi także ważne świadectwo historyczne podboju terytorium Syrii - Palestyny przez muzułmanów.

Pewne wątki z Passio Sanctorum LX Martyrum pojawiają się w innych pismach o charakterze hagiograficznym. Wydawców tekstu ten fakt nieco zaskoczył, lecz elementy zaczerpnięte z historii męczenników z Gazy pojawiają się w zbiorze hagiograficznym z Bolonii, a ściślej w męczeństwie św. Floriana $^{36}$. To tekst uważany za późniejszą formę redakcji epizodu męczeństwa w Gazie w VII w. Pochodzi z dwóch manuskrytów z XV w. Centralna postać Legendy św. Floriana $i$ Towarzyszy to dux et patriarcha ${ }^{37}$. Ta tajemnicza postać wydaje się odpowiadać osobie Sofroniusza ${ }^{38}$. Imię Florian zachowuje w szczątkowej formie imię Sofroniusz. Greckie imię patriarchy było nieznane łacińskim kopistom, więc ci przekształcili je na inne, brzmiące już bardziej swojsko. Na tej podstawie można wnioskować o śmierci Sofroniusza, który naraził się muzułmańskim zdobywcom, chrzcząc muzułmanów i jednając z Kościołem odstępców. Sofroniusz nie miał swojego biografa, czemu trudno się dziwić ze względu na powszechny zamęt i niepewność. Jednak powyższe elementy hagiograficzne uzupełniają skape wiadomości na temat patriarchatu jerozolimskiego w okresie podbojów islamu ${ }^{39}$.

To połączenie postaci świętych Sofroniusza i Floriana można wyjaśnić dzięki chronologii dokumentu o odnalezieniu w 1141 r. szczątków świętych przez mnichów z kościoła św. Szczepana w Bolonii ${ }^{40}$. W XIII w. anonimowy duchowny z Bolonii połączył te fakty z legendą o św. Petroniuszu, który miał przywieźć relikwie męczenników z Ziemi Świętej ${ }^{41}$. Kompilując legendę o św. Florianie uzupełnił ją o teksty z Passio LX Martyrum, gdzie jednak nie ma wzmianki o tym świętym. W Bolonii zresztą powstał w V w. kompleks

369-374; Woods, The 60 Martyrs of Gaza, s. 129-150 (przedruk w: Arab-Byzantine Relations in Early Islamic Times, ed. M. Bonner, The Formation of the Classical Islamic World 8, Aldershot 2004, 429450). Por. także BHL 5672m i 3053b. Dobry komentarz zawierają ASanc, November III 247-250.

${ }^{36}$ Bollandyści wydali ten dokument wspólnie z omawianym męczeństwem. Por. BHL 3053b. Zob. Woods, The 60 Martyrs of Gaza, s. 129 i 146-150.

${ }^{37}$ Legenda S. Floriani et sociorum 5, ed. H. Delehaye, w: tenże, Passio Sanctorum Sexaginta Martyrum, AnBol 23 (1904) 306.

${ }^{38} \mathrm{Na}$ temat patriarchatu Sofroniusza por. Ch. von Schönborn, Sophrone de Jérusalem. Vie Monastique et Confession Dogmatique,Théologie Historique 20, Paris 1972, 83-98.

${ }^{39}$ Por. Woods, The 60 Martyrs of Gaza, s. 137. Autor cytuje najważniejsze opracowania na ten temat.

${ }^{40}$ Por. Sermo de inventione sanctarum reliquiarum. Zob. BHL 6643.

${ }^{41} \mathrm{~W}$ młodości pielgrzymował on do Ziemi Świętej, a następnie został biskupem Bolonii. Por. F. Lanzoni, S. Petronio di Bologna nella storia e nella leggenda, Roma 1907. 
budowli zwany Santo Stefano, który stanowi w opinii ekspertów najstarszą i najwierniej zachowaną kopię jerozolimskich sanktuariów ${ }^{42}$. Dołączono do tego tradycję męczenników z Gazy i św. Floriana, chociaż anonimowy autor mógł wzorować się na Liber Pontificalis Agnellusa z Rawenny, gdzie jest mowa o relikwiach św. Floriana pochodzącego z Noricum ${ }^{43}$. Wysuwa się hipotezę, że tłumacz miał przed sobą oryginalny grecki dokument, bogatszy pod względem faktograficznym od krótszej wersji Passio ${ }^{44}$.

Niedostatki formy w żadnym stopniu nie dyskwalifikują tekstu jako źródła historycznego, wypełniającego luki w dokumentacji tamtej epoki. Pod piórem autora przykłady niewzruszonej wiary z początkowego okresu istnienia Kościoła odżywają w kluczowym momencie podboju Syrii - Palestyny. W okresie najazdu islamskiego rozpowszechniano martyrologię jako wzór postępowania i dla umocnienia zdeprymowanych wiernych wobec jawnej nietolerancji nowych panów Bliskiego Wschodu. Dzieł z tego okresu jest niewiele, ale stanowią znamienne przykłady. Passio męczenników z Gazy uzupełnia relacje historyczne, kronikarskie i teologiczne, związane z konfrontacją chrześcijaństwa z zaborczym islamem ${ }^{45}$. Są faktem kontakty naśladowców Mahometa z biskupem Kościoła etiopskiego i znajomość heterodoksyjnej doktryny chrześcijańskiej, co znalazło zresztą swoje odbicie w Koranie. Chociaż wczesny islam był bardziej tolerancyjny niż w innych okresach, stawiał zawsze warunek bezwzględnego podporządkowania się władzy kalifa, a także porzucenia chrześcijaństwa, nawet jeśli płacono daninę $e^{46}$. Losy żołnierzy-męczenników burzą sielankowe wyobrażenie relacji pierwotnego islamu z innymi wspólnotami religijnymi. Przyjrzyjmy się pokrótce tekstowi Passio Sanctorum LX Martyrum.

3. Opis męczeństwa i jego konteksty. „Umiłowane przez Chrystusa”47 miasto Gaza, było oblegane przez muzułmanów i w końcu zdobyte w dwudziestym siódmym roku panowania cesarza Herakliusza (637) ${ }^{48}$. Przyszli męczennicy byli doskonałymi żołnierzami, którzy ,wiele wiosek i miast chrześcijańskich bronili swoją radą i mieczem przed bezbożnymi Saracenami”49. Wywodzili się oni z miejscowej ludności, stąd być może nadzieja islamskich

${ }^{42}$ Por. D. Neri, Il Santo Sepolcro riprodotto in Occidente, Jerusalem 1971, 51.

${ }^{43}$ Por. H. Delehaye, Les origines du culte des martyres, Bruxelles 1993, 326.

${ }^{44}$ Takiego zdania jest Woods (The 60 Martyrs of Gaza, s. 130).

${ }^{45}$ Odnośnie do źródeł historycznych por. D.J. Constantelos, The Moslem Conquests of the Near East as Revealed in the Greek Sources in the Seventh and the Eight Centuries, „Byzantion” 42 (1972) 329-330.

${ }^{46}$ Odnośnie do haraczu por. Robinson, Neck-Sealing in Early Islam, s. 401-441.

${ }^{47}$ Passio Sanctorum LX Martyrum 1, ed. H. Delehaye: Passio Sanctorum Sexaginta Martyrum, AnBol 23 (1904) 300, thum. własne.

${ }^{48}$ Por. A. Guillou, La Prise de Gaza par les Arabes au VII siècle, „Bulletin de Correspondance Hellenique" 81 (1957) 396-404; W.E. Kaegi, Byzantium and the Early Islamic Conquests, Cambridge 1992, 95-96.

${ }^{49}$ Legenda S. Floriani et sociorum 1, ed. Delehaye, s. 304, thum. własne. 
zdobywców na przyjęcie przez nich religii proroka Mahometa ${ }^{50}$. Legenda $o s ́ w$. Florianie dodaje, że „Saraceni ścigali ich z wyraźną nienawiścią, tak że przyrzeczono tym, którzy by ich pojmali, wielkie honory i bogactwa" ${ }^{51}$. Celem było sprowokowanie odstępstwa od wiary. W przeciwnym razie czekała żołnierzy okrutna śmierć. Akt łaski udzielony pokonanym przez muzułmanów, najwyraźniej nie obejmował żołnierzy garnizonu bizantyjskiego, który brał udział w obronie miasta. Dowódca oddziałów arabskich Ambrus/Amr, złożył żołnierzom propozycję przejścia na islam, co gwarantowało im życie i wolność ${ }^{52}$. „Mieli przed nim porzucić wiarę w Chrystusa i najdroższy oraz dający życie krzyż naszego Pana Jezusa Chrystusa" ${ }^{53}$. Żołnierze odrzucili propozycje i zostali wtrąceni do miejscowego więzienia. Wersja wcześniejsza dodaje, że przed uwięzieniem Ambrus/Amr „rozkazał, aby ich odłączono od żon i dzieci oraz odebrano broń" 54 .

Po trzydziestu dniach skutych kajdanami poprowadzono ich do Eleuteropolis/Bet Guvrin ${ }^{55}$. To miasto palestyńskie odgrywa w opowiadaniu ważną rolę. Passio mówi o fakcie dwukrotnego pobytu męczenników w Eleuteropolis, choć brakuje wzmianki o opuszczeniu tego miasta. To zapewne wina kopisty, który pominął jakiś fragment tekstu. Być może jednak doszło do pomyłki innego rodzaju. Chodziło być może o pobyt na terenie przygranicznym, który obejmowała diecezja Eleuteropolis ${ }^{56}$. Źródła pisane potwierdzają ścisły związek pomiędzy tym miastem a tzw. Saltus Gerariticus, stanowiącym punkt przygraniczny z Idumeą ${ }^{57}$. W południowej Palestynie (Kefar Zachariah)

${ }^{50}$ Wspólnota muzułmańska przedstawia się jako powszechna, przezwyciężające różnice rasowe, społeczne i osobiste. Koran podkreśla, że wierzący są braćmi (por. sura 49, 10). Zob. Koran, thum i kom. J. Bielawski, Warszawa 1986, http://www.planeta islam.com/koran_bielawski.html [dostęp: 11.12.2015].

${ }^{51}$ Legenda S. Floriani et sociorum 1, ed. Delehaye, s. 304, tłum. własne.

${ }^{52} \mathrm{~W}$ Legendzie św. Florianie opowiadanie o zdobyciu Gazy i pojmaniu żołnierzy ma zabarwienie bardziej dramatyczne. Por. tamże.

${ }^{53}$ Artykuł wiary dotyczący ukrzyżowania Chrystusa Pana w chrześcijańskim Credo sprawia, że zbawczy krzyż zajął główne miejsce w pobożności wiernych i nauczaniu pasterzy. Obecność narzędzia Zbawienia, na równi z faktem zmartwychwstania, to koronny argument prawdziwości religii chrześcijańskiej. Taka perspektywa powoduje, że na dalszy plan odsunięte zostały aspekty tego znaku jako synonimu poniżenia i odrzucenia Chrystusa przez Jego lud, chociaż głoszono z całą mocą Chrystusa ukrzyżowanego, jako zgorszenie dla Żydów i głupotę dla pogan (por. 1Kor 1,23). W pewnym sensie te aspekty zostają jakby wchłonięte przez zwycięstwo i chwałę oraz uobecnione przez krzyż. W IV w., gdy posługę biskupa świętego miasta pełnił Cyryl Jerozolimski, nad Jerozolimą pojawił się świetlisty krzyż (7 V 351). Cyryl opisał to wydarzenie w liście do cesarza Konstancjusza (Epistula ad Constantium 3).

${ }^{54}$ Passio Sanctorum LX Martyrum 1, ed. Delehaye, s. 301, tłum. własne.

${ }^{55}$ Por. tamże.

${ }^{56}$ Biskupstwo Saltus po raz pierwszy wzmiankowane jest w $451 \mathrm{r}$. i podlegało metropolii Eleuteropolis.

${ }^{57}$ Od czasów cesarza Wespazjana powstał w tym rejonie obronny pas limes Palaestinae. 
znaleziono w V w. relikwie proroka Zachariasza ${ }^{58}$, stąd kolejne związki tego obszaru z Eleuteropolis ${ }^{59}$. Pisarze chrześcijańscy więc niemal instynktownie łączyli ten teren nie z Gazą, a z Eleuteropolis, mimo sporej odległości pomiędzy tymi ośrodkami ${ }^{60}$.

W Eleuteropolis przyszli męczennicy pozostali dwa miesiące, po czym tam wrócili z niewiadomego miejsca, w którym w międzyczasie przebywali. Po trzech miesiącach poprowadzono ich do Jerozolimy, gdzie złożył im wizytę patriarcha Sofroniusz. Święte miasto niewątpliwie było już wtedy w rękach muzułmanów. Patriarcha:

„przebywał z nimi nocną pora, upominając i prosząc, by nie odstapili od wiary Chrystusa (Christi confessionem non discenderent), który za nas został umęczony" ${ }^{\prime \prime}$.

W przypadku itinerarium męczenników problemy pojawiają się nie przy znanych miastach, jak Jerozolima czy Eleuteropolis, ale w przypadku miejscowości określonej jako Theropolis. Można to wytłumaczyć zniekształceniem Eleuteropolis. Są jednak radykalniejsze rozwiązania, wskazujące że chodzi o Diospolis lub Nikopolis ${ }^{62}$.

Obok nazwy Theropolis pojawiło się określenie Theopolis. To miejsce męczeństwa pierwszej grupy dziesięciu męczenników. Nazwa wskazuje na kalkę

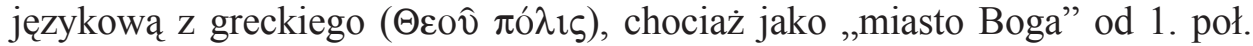
VI w. była określana Antiochia. Niewątpliwie chodzi o Jerozolimę, którą w ten sposób określa tekst łaciński Passio (civitas Dei) ${ }^{63}$.

Kluczowe postaci, jak Ambrus/Amr i Sofroniusz są historykom dobrze znane. Amr Ibn al-'As ${ }^{64}$ dowodził oddziałami arabskimi, które przez Dolinę Arabah dotarły do wybrzeża ${ }^{65}$. Do pierwszej potyczki z wojskami bizantyjskimi doszło w pustynnym rejonie, gdzie Sergiusz, główny dowódca wojskowy (dux) Palestyny, stanął z pięciotysięczną armią, by powstrzymać pochód najeźdźców. Wobec ich przewagi liczebnej postanowił skierować się w okolice

Por. P.A. Kaswalder, Onomastica biblica. Fonti scritte e ricerca archeologica, Collectio Minor 40, Jerusalem 2002, 189.

${ }^{58}$ Wydarzenie to miało miejsce w okresie posługi Jana II. Dla uczczenia tego proroka wzniesiono bazylikę, do której przybywały rzesze pielgrzymów, por. I. Grego, Giovanni II, vescovo di Gerusalemme: le controversie origenista e pelagiana, „Studia Orientalia Christiana - Collectanea” 22 (1989) 102.

${ }^{59}$ Por. Di Segni, The Territory of Gaza, s. 49-52.

${ }^{60}$ Świadczy o tym Teodoret z Cyru (Quaestiones in II Paralipomenon 14, 13).

${ }^{61}$ Passio Sanctorum LX Martyrum 1, ed. Delehaye, s. 301, thum. własne.

${ }^{62}$ Problem ten omawia Woods (The 60 Martyrs of Gaza, s. 129).

${ }^{63}$ Passio Sanctorum LX Martyrum 2, ed. Delehaye, s. 302, thum. własne.

${ }^{64}$ Łac. Ambrus jest transliteracją greckiego odpowiednika imienia muzułmańskiego dowódcy "A $\mu$ ßрos. Por. Nicephorus Constantinopolitanus, Breviarium 23.

${ }^{65}$ Por. Eutychii Patriarchae Alexandrii Annales 276. Zob. Kaegi, Byzantium and the Early Islamic Conquests, s. 96. 
Gazy, gdzie doszło do otwartej bitwy ${ }^{66}$. W walce zginął dowódca bizantyjski. Przebieg tej bitwy opisują ówczesne kroniki syryjskie i arabskie ${ }^{67}$. Amr pojawia się bezpośrednio po kapitulacji Gazy. Dowodzi oddziałami, które zajmują kolejne miasta palestyńskie: Sebaste, Nablus, Jabne, Amwas, Lod i Beit Jibrin. Amr był głównym architektem zajęcia południowo-zachodniej Palestyny. Wraz z czterotysięcznym oddziałem wyruszył samowolnie na Egipt. Arabski wódz rozszerzał dominację wiernych proroka, wykorzystując swoje zdolności dyplomatyczne. Brał udział w inwazji na Cyrenajkę i w konflikcie o sukcesję kalifatu. W tradycji arabskiej Amr Ibn al-'As, ze względu na swoje wszechstronne zdolności w zakresie dyplomacji, wojny i polityki, jest uważany za jednego z $d u h \bar{a} t$ - geniuszy epoki. Świadectwa epigraficzne poświadczają autentyczność tej postaci. W czasie wykopalisk archeologicznych w Khirbat Ruheibeh odnaleziono napis wymieniający „Hakima maulla (tj. uwolnionego), Abdallaha, syna Amr Ibn al-"Asa"68. Jest to jedno z najważniejszych świadectw archeologicznych poświadczających istnienie dowódcy zbrojnej wyprawy Arabów, która dokonała podboju południa Palestyny i Egiptu.

W tekście występuje określenie Ammiras. Być może chodzi o arabskie imię Amir, choć niewykluczone, że dotyczy tytułu emira - dowódcy. André Guillou interpretuje ten tytuł jako odnoszący się do samego kalifa Omara ${ }^{69}$. Trudno jednak sobie wyobrazić, aby Ambrus/Amr dawał rozkazy samemu „władcy wiernych”, jak to opisują obie redakcje męczeństwa. Ponadto kalif Omar przebywał w Jerozolimie dosyć krótko. Opuścił święte miasto przed 639 r., gdy wybuchła zaraza w Emaus - Nikopolis ${ }^{70}$. Termin może więc oznaczać raczej dowódcę niższej rangi. Być może chodziło o Abu Ubajdę, który zastapił Halida Ibn al - Walida na stanowisku dowódcy islamskich oddziałów ${ }^{71}$. Abu Ubajda zmarł w czasie epidemii w Palestynie ${ }^{72}$.

Na scenie dramatu podboju Palestyny pojawia się patriarcha Sofroniusz. Był on następcą Martyriusza po prawie sześciu latach interregnum w Jerozolimie. Negocjował warunki honorowego poddania świętego miasta kalifowi

${ }^{66}$ Chodzi o wioskę Dathin.

${ }^{67}$ Por. Gil, A History of Palestine, s. 38-39.

${ }^{68}$ M. Piccirillo, La Palestina cristiana. I-VII secolo, Bologna 2008, 17.

${ }^{69}$ Por. Guillou, La Prise de Gaza, s. 399.

${ }^{70}$ Miasto oddalone o 160 stadiów (30 km) od Jerozolimy. Znane z epoki machabejskiej jako Ammaus. W niektórych kopiach Ewangelii według św. Łukasza kopiści, znając tylko EmausNikopolis, przed liczbą 60 dopisali jedynkę i tak powstało 160 stadiów. Miejscowość ta była odwiedzana przez pielgrzymów szczególnie w okresie bizantyjskim, aż do 637 r., kiedy została zajęta przez Arabów. Por. K.H. Fleckenstein - L. Fleckenstein, Emmaus-Nicopolis. Ausgrabungen 20012005, Neckenmarkt - Wien - München 2010, 34-35.

${ }^{71}$ Al-Walid dowodził armią arabską aż do decydującej bitwy nad Jarmukiem w 636 roku.

${ }^{72}$ David Woods (The 60 Martyrs of Gaza, s. 143) identyfikuje postać emira z Abu Ubajda. Patriarcha Sofroniusz został skazany na śmierć bez konieczności potwierdzenia wyroku przez wyższego rangą dowódcę, który już wtedy nie żył. 
Omarowi $^{73}$. Sofroniusz pojawił się w opowiadaniu wprowadzając podniosłą atmosferę i budząc głębokie przeżycia religijne. Uosabiał troskę Kościoła o tych, którzy mieli zostać poddani najtrudniejszej próbie.

Kontekst geograficzny związany z Gazą, Jerozolimą i Eleuteropolis jest jak najbardziej wiarygodny. Co prawda nie ma mowy o szlaku nadmorskim, a więc drogach biegnących wzdłuż wschodniego wybrzeża Morza Śródziemnego $^{74}, \mathrm{z}$ tak ważnymi portami, jak Gaza, Cezarea Nadmorska, Tyr, Berytus (Bejrut), Byblos, Antiochia - Seleucja ${ }^{75}$. Z Gazy można było udać się do Aszkelonu i Eleuteropolis ${ }^{76}$.

W Legendzie noszącej imię św. Floriana wiodąca postać opiekuna duchowego i męczennika pojawia się jakby w sposób przypadkowy i niezharmonizowany z resztą tekstu. Z Jerozolimy, gdzie przebywał Florian, anioł w cudowny sposób przenosi go do Gazy, gdzie staje przed uwięzionymi żołnierzami. Pociesza ich, zachęcając do męczeństwa, a gdy zostało ono dokonane, grzebie ich ciała w Eleuteropolis ${ }^{77}$. To powód, dla którego gubernator Ambrus/ Amr skazuje go na śmierć.

Obok postaci emira Jerozolimy i Amr Ibn al-“Asa występuje rzesza „niegodziwych” i „bezbożnych Saracenów” (tenti sunt ab impiis Sarracenis [...] de atheis Sarracenis $)^{78}$. W debacie między chrześcijaństwem a islamem wysu-

${ }^{73}$ Według relacji Eutychiusza kalif przemówił później do patriarchy w następujący sposób: „«Jesteś mi winien życie i dobra, których ci udzieliłem z łaskawości. Naprzód, wskaż mi miejsce, gdzie mógłbym zbudować meczet». Patriarcha odpowiedział: «Dam władcy wiernych miejsce, gdzie może on wznieść świątynię, której królowie rzymscy (Rum) nie byli w stanie zbudować. Tym miejscem jest skała, gdzie Bóg przemówił do Jakuba i [on] nazwał ją bramą niebios. Synowie Izraela nazywali ją świętym świętych i jest pośrodku ziemi. Była ona świątynią synów Izraela [...], [którzy] gdy się modlili zwracali ku niej swe oblicze, gdziekolwiek się znajdowali». Patriarcha poprowadził za rękę Omara do tego miejsca" (Eutychius Alexandrinus, Annales, ed. L. Cheikho, CSCO 51 (Scriptores Arabici 7), Louvain 1960, 17, thum. własne na podstawie przekładu włoskiego: B. Pirone: Eutichio, Patriarcha de Alessandria. Gli Annali, Studia Orientalia Christiana Monographiae 1, Cairo - Jerusalem 1987, 335-337). Opowiadanie na temat pertraktacji Sofroniusza z kalifem wzbudza dyskusje wśród historyków. Zob. O. Grabar, The Shape of the Holy. Early Islamic Jerusalem, Princeton 1996, 44-51, nota 63.

${ }^{74}$ Droga ta zapewniała połączenie Egiptu z siecią komunikacyjną Azji Mniejszej.

${ }^{75}$ Biblia wspomina o ,drodze do morza” (Iz 9, 1), łączącej Egipt z Babilonem. Ten szlak nosi także nazwę Via Maris. Ta droga wiodła przez zachodni Synaj i stamtąd wzdłuż wybrzeża kraju Filistynów. Jej odnoga biegła wybrzeżem morskim, stąd inna jej biblijna nazwa: „droga prowadząca do ziemi filistyńskiej” (Wj 13, 17), gdyż wiodła z Gazy do Aszdod i Joppy. By ominąć mokradła równiny Szaronu, za Joppą skręcała na wschód i dochodziła do miasta Megiddo.

${ }^{76}$ Także z Gazy do Beer-Szeby, podróżując następnie szlakiem łączącym Mampsis na Negewie z Hebronem i Jerozolimą.

${ }^{77}$ Por. Legenda S. Floriani et sociorum 4, ed. Delehaye, s. 306.

${ }^{78}$ Passio Sanctorum LX Martyrum 1, ed. Delehaye, s. 300-301, tłum. własne. Na temat etymologii słowa „Saracen” powstało wiele hipotez, jest jednak pewne, że określenie to pochodzi jeszcze z czasów przedchrześcijańskich. Termin ten wywodzi się czasami od nazwy jednego z plemion jemeńskich - Saracen, którą przytacza Pliniusz (Geographia V 17, 3). Inni uczeni dowodzą, że słowo to pochodzi ze zniekształconej nazwy Hagarini, którą określano biblijnych potomków Izmaela. Do 
wano w stosunku do wiernych Mahometa oskarżenia, iż są oni zwolennikami niewłaściwego kultu, prowadzącego do niemoralnego postępowania. Chodziło być może o obcość wobec cywilizacji bizantyjskiej, co zobowiązywało do odrzucenia islamu za pomocą wszelkich możliwych środków. W Legendzie $o$ św. Florianie Saraceni uważani są wręcz za pogan czczących swoje bożki. Florian jest nakłaniany „by uczcił jego bogów (deos suos colere)”. Sam natomiast Amr nie był zdolny pojać , głupoty i oszustwa swoich bożków" "79, czego wyrazem było to, że nawet modlitwę męczennika utożsamiano z czarami ${ }^{80}$. Autor Legendy najwyraźniej nie miał żadnych obiektywnych informacji o islamie, mimo, że pierwsze $\mathrm{w}$ dziejach międzyreligijne spotkanie chrześcijan i muzułmanów odbyło się 631 r. w Medynie ${ }^{81}$. Św. Jan z Damaszku ${ }^{82}$ wymienił islam wśród stu trzech znanych wówczas herezji. Jego polemiczne pisma, zwłaszcza Disceptatio christiani et saraceni, były skierowane przeciwko muzułmanom ${ }^{83}$. Posądzenia Arabów o politeizm to przysłowiowe odbijanie piłeczki, bowiem właśnie przeciwko chrześcijanom takie oskarżenia formułowali muzułmanie ${ }^{84}$. Według islamu każdy grzech, który popełni człowiek, będzie przez Boga wybaczony, oprócz jednego grzechu - politeizmu. Koran nie jest przejrzysty w wypowiedziach na temat relacji muzułmańsko-chrześcijańskich i - ogólnie mówiąc - wydaje negatywny sąd na temat chrześcijaństwa. Jego wyznawcom zarzuca się fałszowanie doktryny o Bogu, a naukę o bóstwie Jezusa Chrystusa i Trójcy Świętej określano jako wielkie oszustwo ${ }^{85}$, głoszone przez niewiernych i bałwochwalców ${ }^{86}$. Chrześcijanie odpłacali muzułmanom pięknym za nadobne... Powściągliwość autora Passio w kwestiach doktrynalnych jest warta odnotowania.

przyjęcia tej hipotezy skłaniają wypowiedzi Euzebiusza z Cezarei i Prokopiusza z Gazy. Ta specyficzna nazwa określająca wyznawcę islamu z Bizancjum poprzez krzyżowców przeszła do Europy. Por. F. Bocheński, Saraceni, w: Mały Stownik kultury świata arabskiego, red. J. Bielawski, Warszawa 1971, 455; R.W. Southern, Western views of Islam in the Middle Ages, Cambrige 1962, 18.

${ }^{79}$ Legenda S. Floriani et sociorum 5, ed. Delehaye, s. 306, tłum. własne.

${ }^{80}$ Por. tamże.

${ }^{81}$ Opis w 3. surze Koranu.

${ }^{82}$ Jak wiadomo Damasceńczyk pochodził z chrześcijańskiej rodziny w służbie kalifów, znał więc islam oraz kulturę arabskich najeźdźców. Na temat tej postaci por. B. Studer, Giovanni Damasceno, NDPAC II 2229-2232.

${ }^{83}$ Por. szeroką panoramę według V. Poggi, Fede e cultura nel cristianesimo e nell'islam primitivi, w: Il mondo islamico tra interazione e acculturazione, ed. A. Bausani - B. Scarcia Amoretti, Roma 1981, 99-116.

${ }^{84}$ Por. Koran, sura 40, 4-6. Zob. A. Fattal, Le statut légal des non-Musulmans en pays d'Islam, Beirut 1958; Y. Friedmann, Tolerance and Coercion in Islam: Interfaith Relations in the Muslim Tradition, Cambridge 2003; M.R. Cohen, Under Crescent and Cross: The Jews in the Middle Ages, Princeton 1994, 52-74. Tezy wysuwane przez Cohena odnośnie do stosunku muzułmanów do Żydów można przenieść na grunt relacji islamsko-chrześcijańskich.

${ }^{85}$ Por. Koran, sura 18, 5.

${ }^{86}$ Por. tamże, sury 5,$17 ; 23 ; 19,30-31$. 
Późniejsza redakcja męczeństwa nie precyzuje dokładnie czasu, jaki upłynął pomiędzy uwięzieniem a egzekucją pierwszej grupy dziesięciu męczenników. Przypuszcza się, że pomiędzy zdobyciem Gazy a męczeństwem żołnierzy chrześcijańskich upłynęło 17 miesięcy. Autor opisu nie starał się jednak zharmonizować podawanej przez siebie chronologii z latami panowania cesarza Herakliusza. Rozbieżności w datowaniu być może zostały spowodowane pomyłką w zapisie cyfrowym dokonanym przez kopistę. Autor wcześniejszego tłumaczenia Passio opisuje, że w czasie przetrzymywania w świętym mieście ${ }^{87}$ żołnierze otrzymali kolejną propozycję odstępstwa od wiary. Tym razem dzieje się to na podstawie listu napisanego „, diabelskiego natchnienia"88, skierowanego do emira miasta świętego ${ }^{89}$. Amr zobowiązywał tego zarządcę Jerozolimy, by:

„udał się do świętych męczenników w więzieniu i namawiał ich do porzucenia wiary [w Chrystusa]. Jeśliby zgodzili się wyrzec Chrystusa, zostaną im zdjęte kajdany, a oni [sami] odesłani z wielkimi honorami. Gdyby nie podporządkowali się [poleceniu], zostanie ścięty ich dowódca wraz z dziewięcioma innymi, w ich obecności” ${ }^{\prime}$.

Istnieją znaczne różnice pomiędzy męczeństwem żołnierzy z Gazy a dziejami innych chrześcijan, którzy oddali życie za wiarę w okresie Omajjadów ${ }^{91}$. Pojawiły się nawet przypuszczenia, że w przypadku żołnierzy cesarskich nie chodziło o odrzucenie propozycji przyjęcia islamu ${ }^{92}$, lecz o zamiar zamordowania dowódcy arabskiego. Patriarcha Sofroniusz odwiedzał nocą żołnierzy i zachęcał do naśladowania przykładu czterdziestu męczenników z Sebaste w Kapadocji. Byli oni żołnierzami należącymi do słynnego XII legionu rzymskiego zwanego Fulminata, którzy oddali życie za Chrystusa w okresie prześladowań cesarza Licyniusza (306-323) ${ }^{93}$. Był to wspaniały przykład męstwa dla tych, którzy nie zgodzili się na odstępstwo od wiary.

Wizyta patriarchy była preludium męczeństwa. Żołnierze chrześcijańscy

„nie podporządkowali się poleceniom emira, lecz wspólnie wyznali swoją wiarę w naszego Pana Chrystusa. Wtedy rozgniewany emir zgromadził świętych poza miastem, naprzeciw jego bram i rozkazał ściąć ich dowódcę

\footnotetext{
${ }^{87}$ Ich pobyt w tym dokumencie był określony na dziesięć miesięcy.

${ }^{88}$ Passio Sanctorum LX Martyrum 1, ed. Delehaye, s. 301, thum. własne.

${ }^{89}$ Arabski tytuł książęcy stał się pod jego piórem imieniem własnym.

${ }^{90}$ Passio Sanctorum LX Martyrum 1, ed. Delehaye, s. 300, thum. własne.

${ }^{91}$ Panowanie dynastii Omajjadów (lub Umajjadów) przypada na lata 661-750.

${ }^{92}$ Por. Woods, The 60 Martyrs of Gaza, s. 142.

${ }^{93}$ Opis ich męczeństwa można poznać na podstawie świadectwa pochodzącego z Syrii, sporządzonego wkrótce po bohaterskiej śmierci legionistów z Sebaste. Kazania na ich temat głosili tacy autorzy, jak Bazyli Wielki i Grzegorz z Nyssy. W Hymni in SS. XL Martyres uczcił ich Efrem Syryjczyk. O relikwiach tych męczenników w Konstantynopolu wspomina Hermiasz Sozomen (HE IX 2).
} 
[Kallinikusa] oraz dziewięciu innych [...]. Męczennicy Chrystusa zginęli 11 listopada"94.

Wyrok na żołnierzach chrześcijańskich został wykonany poza miastem, ale blisko bramy (foras civitatem ante portas) ${ }^{95}$. Ciała męczenników zostały uroczyście pogrzebane przez patriarchę Sofroniusza „w jednym miejscu, gdzie kazał wznieść oratorium poświęcone św. Szczepanowi, pierwszemu męczennikowi (Protomartyr)" "96. Wyjaśnienie to nie jest bez znaczenia dla łacińskich czytelników, bowiem w Rzymie od 2. poł. V w. stał kościół Santo Stefano Rotondo. Wymiary tej świątyni dokładnie odpowiadały rotundzie Grobu Pańskiego w Jerozolimie ${ }^{97}$.

Zarówno opowiadanie o okolicznościach śmierci, jak i miejsce pochówku pierwszej grupy żołnierzy łączą się z postacią pierwszego męczennika. Kult św. Szczepana był w Palestynie już wtedy ugruntowany, bowiem pamięć o nim odżyła na początku V w. Wtedy pojawiły się doniesienia o objawieniu się we śnie prezbiterowi Lucjanowi miejsca, gdzie znajdowały się relikwie świętego Szczepana. W 415 r. w Kafar Gamala, miejscowości oddalonej od Jerozolimy o około $30 \mathrm{~km}$, prezbiterowi Lucjanowi ukazał się we śnie rabbi Gamaliel, nauczyciel św. Pawła Apostoła ${ }^{98}$. Objaśnił on, że po ukamienowaniu św. Szczepana nakazał zabrać jego zwłoki i pochował w swojej posiadłości99. Obok szczątków męczennika spoczęli także Gamaliel i jego syn ${ }^{100}$. W V w. $\mathrm{z}$ inicjatywy cesarzowej Eudokii ${ }^{101}$ wzniesiono w świętym mieście bazylikę ku czci pierwszego męczennika. Kult pierwszego męczennika w Palestynie był niezwykle żywy także w VII stuleciu. Obok Grobu Pańskiego był ważny

${ }^{94}$ Passio Sanctorum LX Martyrum 2, ed. Delehaye, s. 302, tłum. własne. Oprócz dowódcy zostali ścięci z oddziału zwanego Scythi: Imeriusz, Illustriusz, Teodor, Szczepan, a z oddziału Voluntarii: Piotr, Paweł, Teodor i dwóch Janów.

${ }^{95}$ Por. tamże.

${ }^{96}$ Tamże, tłum. własne.

${ }^{97}$ Por. E. Rizzi, Santo Stefano Rotondo a Roma, w: Rotonde d'Italia. Analisi tipologica della pianta centrale, ed. V. Volta, Milano 2008, 150-154.

${ }^{98}$ Wymieniają go Dz 5, 34 i z wdzięcznością wspomina sam Apostoł (por. Dz 22, 3).

${ }^{99}$ Kafar Gamala - po hebr. ,posiadłość Gamaliela”. Ciało pierwszego męczennika spoczęło w nowym grobie, a Gamaliel urządził pogrzeb na swój koszt, jak wcześniej uczynił Nikodem z ciałem Pana Jezusa. Miejscowi biskupi udali się na miejsce znalezienia cennych szczątków, aby osobiście uczestniczyć w rozpoznaniu relikwii (415). W 438 r. uczynił to nawet Cyryl Aleksandryjski (por. Basilius Seleucensis, Oratio 42). Zob. Perrone, La chiesa di Palestina e le controversie cristologiche, s. 49. Na temat odnalezienia relikwii św. Szczepana i ich rozdzielenia por. E.D. Hunt, Holy Land Pilgrimage in the Later Roman Empire AD 312-460, Oxford 1982, 211-220.

${ }^{100}$ Czcigodny nauczyciel przyjął wiarę chrześcijańską wraz z synem Abybosem. Por. A. Strus, La passione di Santo Stefano in due manoscritti greci, „Salesianum” 58 (1996) nr 1, 21-61; tenże, L'origine de l'apocryphe grec de la Passion de S. Étienne: à propos d'un texte de deux manuscrits récemment publiés, EL 112 (1998) 18-57.

${ }^{101}$ Por. wyczerpujący szkic I. Grego, Eudossia imperatrice, primadonna e santa, „Studia Orientalia Christiana - Collectanea" 25 (1992) 335-360; Na temat biografii Eudokii por. przede wszystkim H.G. Beck, Eudokia, RACh VI 844-848. 
element taumaturgiczny, który należało połączyć ze zjawiskiem „religijności ludowej"102. Patriarcha Sofroniusz kultywował te tradycje, a fakt męczeństwa ożywił nabożeństwo chrześcijan do męczenników. Hagiograf nie omieszkał przytoczyć imion bohaterów wiary i nazw oddziałów, w których służyli.

Wiadomość o męczeństwie chrześcijan w Gazie w lakonicznej formie przekazało Martyrologium z VIII wieku ${ }^{103}$. W tym dokumencie jest wzmianka o Jerozolimie jako miejscu męczeństwa i nawiązanie do postaci czterdziestu męczenników z Sebaste ${ }^{104}$. W legendzie, gdzie dominuje postać św. Floriana, opis męczeńskiej śmierci żołnierzy poprzedza objawienie anioła „,W wielkim blasku" 105 . Wzmianka o aniele to po prostu wskazanie na posłańca ${ }^{106}$, którym mógł być jakiś zaufany przedstawiciel kleru, może nawet mnich. Hagiograf redagujący wcześniejszą wersję podał informację, że męczenników w Jerozolimie i Eleuteropolis nawiedził sam Sofroniusz. W opisie hagiograficznym te fakty mogły przekształcić się w objawienie anioła. Ów anioł - wysłannik

„pocieszał [męczenników], aby nie obawiali się prób i tortur ze strony Ambrusa i nie wyrzekli się wiary i miłości Chrystusa. Za te trudy Chrystus przygotował dla nich niewiędnące wieńce" ${ }^{107}$.

Florian dowiedział się, że jemu „przeznaczona jest większa próba”, aby potem mógł otrzymać „chwalebniejszy wieniec i nagrodę zwycięstwa”"108. Florian miał wizję przyszłej chwały męczenników ${ }^{109}$.

${ }^{102} \mathrm{~W}$ świetle niektórych faktów wydaje się nieprawdziwa opinia, że ,miejsca święte Starego Testamentu były zbyt mocno związane z judaizmem, aby władza kościelna z lekkim sercem mogła pozwolić wiernym z Palestyny na otoczenie ich czcią" (Le christianisme antique et son contexte religieux, éd. M. Simon, Tübingen 1981, 562).

${ }^{103}$ Por. Le Martyrologe d'Adon, ses Deux Familles, ses Trois Recensions, Texte et Commentaire, éd. J. Dubois - G. Renaud, Paris 1984, 37.

${ }^{104}$ Por. Woods, The 60 Martyrs of Gaza, s. 131-132.

${ }^{105}$ Legenda S. Floriani et sociorum 2, ed. Delehaye, s. 304, thum. własne.

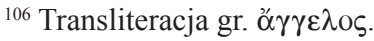

${ }^{107}$ We wczesnej tradycji chrześcijańskiej symbolika wieńca opiera się na Nowym Testamencie. Jest to więc znak zwycięstwa i synonim nagrody wiecznej. W tym czasie wieniec staje się nieodłącznym atrybutem męczenników, którzy ginęli w okresie prześladowań (por. Hermas, Pastor Parabola VIII 2, 1; Cyprianus, Epistula 10; tenże, De lapsis 4). Żołnierze cesarza Konstantyna (IV w.) nosili tarcze z monogramem Chrystusa otoczonym wieńcem. Z tego samego okresu pochodzą wzmianki o zwyczaju zdobienia wieńcami wizerunków świętych. Zwyczaj ten stopniowo się rozwijał i przy uroczystych okazjach girlandy i wieńce zdobiły również kościoły i ołtarze. Dość powszechne stało się przedstawianie na starożytnych mozaikach postaci świętych niosących wieńce, a atrybut ten z czasem stał się powszechnym symbolem świętości i zwycięstwa zbawionych. W okresie pokonstantyńskim zerwano z pogańską funkcjonalnością wieńca i przeniesienia jego znaczenia w sferę wyłącznie symboliczną jako corona vitae aeternae. Por. A. Viciano, Corona, NDPAC II 1190-1193; H. Karczewska, Funkcja wieńców w tradycji antycznej, „Seminare” 26 (2009) 345-349.

${ }^{108}$ Legenda S. Floriani et sociorum 2, ed. Delehaye, s. 304, tłum. własne.

${ }^{109}$ Tamże 1, ed. Delehaye, s. 304-305, thum. własne. 
Wydaje się bardzo znamienne, że także męczeństwo Floriana ma znamiona opisu heroicznej śmierci pierwszego męczennika. Podobnie jak Szczepan, także i on odważnie przemawia ${ }^{110}$. Dostępuje również wizji chwały Bożej ${ }^{111}$. Gdy więc:

„uklęknął, wzniósł ręce i oczy ku niebu, wychwalając Chrystusa, który uczynił go godnym śmierci dla swej miłości, ujrzał Chrystusa z wieloma zastępami świętych i usłyszał głos mówiący: Pójdź o Florianie, przyjdź, bo dziś wydałeś najobfitszy owoc z twojego kwiatu i przyjmiesz koronę wiecznego panowania i chwały. Na chwałę wszechmocnego Boga. Amen"112.

Widać tu dosyć typowy zabieg literacki polegający na grze słów: Florian - flos. Wzmianki o kwiatach spotyka się w homiliach patrystycznych odnoszacych się przede wszystkim do Wielkanocy ${ }^{113}$. Hagiograf opisuje zewnętrzne znaki świętości Floriana w ciężkim więzieniu: w celi rozbłysło wspaniałe światło i unosił się, ,słodki zapach, jakby kwiatów o najróżniejszych kształtach i kolorach"114. Światłość i miłą woń uważano za zmysłowo uchwytne znamiona ingerencji świata nadprzyrodzonego w świat ziemski. Znaki te wskazują na świętość opisywanej postaci ${ }^{115}$. Wśród autorów wczesnochrześcijańskich wonności kojarzono na ogół ze sferą nadprzyrodzoności ${ }^{116}$. W takim właśnie znaczeniu postrzegano przyjemne zapachy wyczuwalne w otoczeniu świętych osób, szczególnie w chwili śmierci (odor sanctitatis) ${ }^{117}$.

${ }^{110}$ Por. tamże 5, ed. Delehaye, s. 306.

${ }^{111}$ Por. tamże 5-6, ed. Delehaye, s. 306-307.

112 Tamże 6, ed. Delehaye, s. 307, tłum. własne.

${ }^{113}$ Kwiaty odnosiły się do nadziei zmartwychwstania, wiecznej wiosny i niebiańskiej radości w raju. Por. np. Ephraem Syrus, Hymni de resurrectione 2; Zeno Veronensis, Tractatus II 45.

${ }^{114}$ Legenda S. Floriani et sociorum 5, ed. Delehaye, s. 306, thum. własne.

${ }^{115}$ Wcześniej hagiograf opisuje znaki powodujące, że strażnicy padają u stóp św. Floriana, prosząc o chrzest. Por. tamże.

${ }^{116}$ Według Orygenesa „kto ma czysty oddech i dzięki znajomości Słowa Bożego może biec za Nim w woni Jego zapachów, ten jest «nosem», który czuje duchową wonność" (Origenes, Scholia in Canticum Canticorum VII, PG 17, 281D, thum. S. Kalinkowski, w: H. Urs von Balthasar, Orygenes. Duch i ogień, BOK 4, Kraków - Warszawa 1995, 254). W dwa wieki później Cyryl Aleksandryjski, mówiąc o boskiej naturze Zbawiciela świata, przekonuje: „Paweł pisze do wiernych: «Bogu niech będą dzięki za to, że pozwala nam zawsze zwyciężać w Chrystusie i roznosić po wszystkich miejscach woń Jego poznania. Jesteśmy bowiem miłą Bogu wonnością Chrystusa» (2Kor 2, 14-15). W Chrystusie wdychamy woń Boga Ojca [...]. [Wszystko, co istnieje] wydaje sobie właściwy zapach. Jakże więc Chrystus może być dla nas wonią poznania Boga Ojca, jeśli nie wierzymy w jego bóstwo [...]? Dzięki Niemu i w Nim poczuliśmy woń poznania Ojca i nią zostaliśmy ubogaceni” (Cyrillus Alexandrinus, De sancta et consubstantiali Trinitate 3, PG 75, 856C, thum. własne). Tego typu porównań używał Grzegorz z Nyssy poruszając kwestię poznania Boga: „Wszystkie przymioty dają blade wyobrażenie o woni boskości, którą całe stworzenie zachowuje" (Gregorius Nyssenus, In Canticum canticorum 1, ed. H. Langerbeck, GNO 6, Leiden 1960, 36-37, thum. M. Przyszychowska: Grzegorz z Nyssy, Homilie do Pieśni nad pieśniami, ŹMT 43, Kraków 2007, 34).

${ }^{117}$ Bardzo sugestywny pod tym względem jest opis śmierci żyjącego na pustyni mnicha starca Sisoesa. Opowiadano o nim, że „kiedy miał umierać i ojcowie [świętobliwi mnisi] siedzieli wokół 
Podobnych opisów próżno szukać w wersji wcześniejszej Passio LX Martyrum. Tekst po prostu relacjonuje, że po śmierci dowódcy i towarzyszy

„pozostali święci powrócili do więzienia. Emir ${ }^{118}$ napisał list do Ambrusa: «Uczyniłem wszystko według polecenia. Gdy więc żołnierze ci nie podporząakowali się, zadekretowałem karę śmierci, pozostałych zamknąłem w więzieniu. Napisz, co uważasz za stosowne, bym uczynił»"

Prześladowanie ocalałych żołnierzy autor uważa za inspirację diabelską: „Po trzydziestu dniach diabeł znowu zasiał [zło] w sercu Ambrusa i rozkazał emirowi przysłać w kajdanach świętych" ${ }^{120}$. Działanie Amra jest inspirowane przez demoniczne siły ${ }^{121}$, wrogie prawdzie objawionej. Jest to echo przekonania chrześcijan pierwszych wieków, że to podszepty diabła czynią z nich winowajców wobec pogan:

„[Tak więc] męczennicy Chrystusa stanęli wspólnie przed Ambrusem. Rozkazał [on], aby przyprowadzono ich żony i dzieci. Gdy ich wprowadzono, rzekł Ambrus do świętych męczenników Chrystusa: «Jak długo pozostaniecie zatwardziali (dure cervice estis) i nie będziecie uczestniczyć w naszych obrzędach? Jeśli się zgodzicie [na naszą propozycje]], odzyskacie wasze żony i dzieci, będziecie jak my i otrzymacie zaszczyty jak każdy z nas. Jeśli nie [zgodzicie się], będziecie cierpieć podobnie jak [wasi poprzednicy]». Wtedy święci męczennicy odpowiedzieli wspólnie Ambrusowi: «Nic nas nie odłączy od miłości Chrystusa; ani żony, ani dzieci, ani żadne z bogactw tego świata, lecz jesteśmy sługami Chrystusa, Syna Boga żywego. Jesteśmy gotowi zginąć dla Tego, który za nas umarł i zmartwychwstał». Gdy to posłyszał okrutny Ambrus, pełen gniewu i z okrutnym obliczem, rozkazał, aby thum Saracenów otoczył świętych męczenników i tak bezbożnie ich zabił z powodu wiary w Chrystusa. Gdy zaś święci skończyli żywot, przybyli jacyś miłujący Chrystusa ludzie, by zabrać ich ciała, płacąc trzy tysiące solidów. Oni to pochowali męczenników Chrystusa z wielką czcią, składając [ich ciała] w Eleuteropolis i wznieśli tam kościół, gdzie jest czczona Przenajświętsza, Dająca Życie i Współistotna Trójca (sancta, vivificatrix et consustantialisTrinitas)"122.

niego, jego twarz zajaśniała jak słońce (por. Mt 17,2) [...] i powiedział do nich: «Patrzcie, Pan przyszedł i mówi: Przynieście mi naczynie pustyni» (por. Oz 9, 15). I zaraz oddał ducha (por. J 19, 13) [...], a cała cela napełniła się piękną wonią (por. J 12, 3)" (Apophtegmata Patrum 14 (817), PG 65, 396C, thum. M. Borkowska, w: Apoftegmaty Ojców Pustyni, t. 1: Gerontikon. Księga Starców, ŹM 4, Kraków - Tyniec 2004, 443-444).

${ }^{118}$ Dosł. Ammiras.

${ }^{119}$ Passio Sanctorum LX Martyrum 3, ed. Delehaye, s. 302, thum. własne.

${ }^{120}$ Tamże, tłum. własne

${ }^{121}$ Tego typu opinię można spotkać u Orygenesa: „Demony wyruszają w bój przeciwko zbawieniu tych, którzy poświęcają się Bogu” (Origenes, Contra Celsum VIII 64, ed. M. Borret, SCh 150, Paris 1969, 320, thum. S. Kalinowski: Orygenes, Przeciw Celsusowi, Warszawa 1986², 419).

${ }_{122}$ Passio Sanctorum LX Martyrum 3, ed. Delehaye, s. 302-303, tłum. własne. Hagiograf przytacza ich imiona. „Z oddziału Scytii: Jan, Paweł i inny Jan, Paweł, Fotinus, Zitas, Eugeniusz, Musilius, 
Nieugięta postawa męczenników wskazuje na szczególną wiarę w zbawczą śmierć Zbawiciela i Jego zmartwychwstanie. Ten punkt chrześcijańskiego Credo być może był powodem umieszczenia znaczącej inskrypcji na temat Chrystusa na wewnętrznej stronie jednej z ośmiu arkad w meczecie Kopuły Skały w Jerozolimie:

„Boże, błogosław swego Posłańca i swego Sługę Jezusa, syna Maryi. Niech on będzie błogosławiony w dniu swych narodzin, w dniu swojej śmierci oraz w dniu, w którym powstanie spośród umarłych"123.

Tekst świadczy, że według muzułmanów, Jezus jest tylko i wyłącznie człowiekiem i jednym z proroków. Islam odrzuca fakt krzyżowej śmierci Chrystusa i wiarę w Jego zmartwychwstanie ${ }^{124}$. Miejsce pochówku męczenników podkreśla odrzucany przez muzułmanów kolejny dogmat - trynitarny. Podobny wydźwięk ma końcowa doksologia o wyraźnych znamionach liturgicznych: „W czasie władania naszego Pana, Jezusa Chrystusa, który z Ojcem i Duchem 'Swiętym żyje i króluje na wieki wieków. Amen"125.

Dawid Woods doprowadza datację męczeństwa do listopada i grudnia roku $639^{126}$. Z kolei Hippolyte Delehaye preferuje datę o rok wcześniejszą ${ }^{127}$. Epizod zdobycia Gazy, w którego kontekście rozegrał się dramat męczeństwa sześćdziesięciu żołnierzy chrześcijańskich, nie zakończył podboju Palestyny przez Arabów ${ }^{128}$. Ostatnim miastem, które stało się łupem muzułmanów była

Jan, Szczepan, Teodor, Jan ojciec i syn Teodor, Jerzy, Teopentus, Jerzy, Sergiusz, Jerzy, Teodor, Quiriacus, Jan, Zitas i Jan, Filoksen, Jerzy, Jan, Jerzy; z oddziału Voluntarii: Teodor, Epifaniusz, Jan, Teodor, Sergiusz, Jerzy, Tomasz, Szczepan, Konon, Teodor, Paweł, Jan, Jerzy, Jan i Jan, Paulin, Galumas, Habramius, Mermicius i Marines". (tamże 4, ed. Delehaye, s. 303, thum. własne). Warto zwrócić uwagę na częste występowanie takich imion, jak: Jan, Jerzy i Teodor. Nie brak także męczennika o imieniu Szczepan. Na temat pochówku męczenników w Eleuteropolis por. B. Bagatti, Il cristianesimo ad Eleuteropoli, „Liber Annuuus SBF” 22 (1972) 116.

${ }^{123}$ Jest to parafraza sury 19, 33. Por. S. Blair, What Is the Date of the Dome of the Rock?, w: Bayt al-Maqdis, ed. J. Raby - J. Johns, part 1, Oxford 1992, 87. Muzułmanie odrzucają katego-

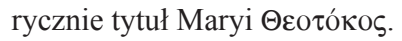

${ }^{124}$ Wypływa to z podstawowej przesłanki zbędności Odkupiciela upadłej ludzkości, stąd nie jest potrzebny również krzyż. Muzułmanie nie rozumieją chrześcijańskiej prawdy wiary o Wcieleniu Syna Bożego. Uważają, że zarówno tytuł Syn Boży, jak i wiara we Wcielenie stanowią podważenie prawdy o istnieniu jednego, jedynego Boga.

${ }^{125}$ Passio Sanctorum LX Martyrum 4, ed. Delehaye, s. 303, thum. własne.

${ }^{126}$ Por. Woods, The 60 Martyrs of Gaza, s. 134.

${ }^{127}$ Por. Delehaye, Passio Sanctorum Sexaginta Martyrum, ed. Delehaye, s. 291.

${ }^{128} \mathrm{~W}$ tekstach źródłowych daje się zauważyć pewne sprzeczności odnośnie do skutków działań skierowanych przeciwko Gazie. Klasyczną wizje przedstawiają F.M. Donner (The Early Islamic Conquests, Princeton 1981) i W.E. Kaegi (Byzantium and the Early Islamic Conquests, Cambridge 1992). Odnośnie do trudności w interpretacji tekstów arabskich por. S. Leder, The literary use of the Khabar: a basic form of historical writing, w: The Byzantine and Early Islamic Near East, t. 1: Problems in the Literary Source Materials, ed. A. Cameron - L.I. Conrad, Studies in Late Antiquity and Early Islam 1, Princeton 1992, 277-315. 
Cezarea Nadmorska. Metropolia Palestyny została zdobyta po długim oblężeniu w 640 roku. Miasto zostało zrabowane i spalone. Przy tej okazji spłonęła doszczętnie biblioteka, której twórcą w tym mieście był Orygenes.

Podjęto natomiast proces stopniowej islamizacji Jerozolimy - ,miasta chrześcijan" 129 , który rozpoczął się od zajęcia Wzgórza Świątynnego i wzniesienia budowli, które wskazywały na to, że islam był kontynuacją judaizmu i chrześcijaństwa. Źródła greckie i syryjskie wspominają o zawaleniu się pierwszego meczetu na Wzgórzu Moria w Jerozolimie, spowodowanym trzęsieniem ziemi. Sa znane dwa kataklizmy tego typu: we wrześniu 634 r. i w czerwcu 659 roku. Być może pomiędzy tymi datami miała miejsce podobna katastrofa. $Z$ pewnością dostrzegano w tych faktach ,znaki”, które rozbudzały fanatyczne nastroje ${ }^{130}$.

Po okresie podbojów, będących zawsze destrukcyjnymi dla społeczności, arabscy muzułmanie pozostawiali w spokoju podbitą ludność. Zapewniał to tzw. „pakt kalifa Omara”. Mimo wątpliwości, czy rzeczywiście chodzi o dokument wydany przez tego władcę, czy późniejsze o dwa wieki pismo, jest on miarodajny w wielu kwestiach ${ }^{131}$. Pod rządami muzułmańskimi chrześcijanie, podobnie jak wyznawcy judaizmu, otrzymuja prawa, gwarantowane wspomnianym aktem ${ }^{132}$. Dotyczy to swobody kultu religijnego, autonomii w decydowaniu o kwestiach religijnych, dbania o miejsca kultu. Należy oczywiście zaznaczyć, że ten akt prawny czynił z chrześcijan i innych niemuzułmanów obywateli drugiej kategorii, chociaż początkowo chrześcijanie mieli dość znaczne wpływy w państwie pomimo odmienności religii. Byli szanowanymi obywatelami ze względu na swoje umiejętności i wykształcenie ${ }^{133}$.

Analizując przemiany historyczne widać, że od VII w. zarówno islam, jak i chrześcijaństwo Bliskiego Wschodu, przeżywały głębokie transformacje kulturowe i społeczne. Obydwie wspólnoty ostatecznie zachowały nienaruszona tożsamość religijną, jednak zaszczepiły ją na zupełnie nowych fundamentach kulturalnych. Krok po kroku chrześcijanie Bliskiego Wschodu przekształcili religijne formy z kultur syryjskiej, greckiej i koptyjskiej na kulturę arabską.

${ }^{129}$ Por. Piccirillo, La Palestina cristiana, s. 200.

${ }^{130}$ Kroniki wspominają o nakazie usuwania krzyży z wielu kościołów w Jerozolimie. Por. Woods, The 60 Martyrs of Gaza, s. 136, nota 17.

${ }^{131}$ Por. M.R. Cohen, What was the Pact of 'Umar? A Literary-Historical Study, „Jerusalem Studies in Arabic and Islam" 23 (1999) 129-130; A. Noth, Abgrenzungsprobleme zwischen Muslimen und Nicht-Muslimen: Die 'Bedingungen 'Umars (ǎššurūt al-'umariyya)' unter einem anderen Aspekt gelesen, „Jerusalem Studies in Arabic and Islam” 9 (1987) 290-315. Opracowanie to zostało przetłumaczone na angielski zob. M. Muelhaeusler, Problems of Differentiation Between Muslims and Non-Muslims: Re-Reading the „Ordinances of 'Umar" (al-shurūt. al-'umariyya), w: Muslims and Others in Early Islamic Society, ed. R. Hoyland, Aldershot 2004, 103-124.

${ }^{132}$ Chrześcijanie, którzy bezwzględnie podporządkowali się władzy muzułmańskiej mieli zagwarantowane nietykalność osobistą, utrzymanie dóbr materialnych i miejsc kultu (status tzw. dhimmi). Por. R. Stäger, Chrétiens d'Arabie affrontés à l'Islam. Les deux „,pactes” de Najran (632 et 897), POC 48 (1998) 249-293.

${ }^{133}$ Jest to sytuacja ujawniająca się w arabskich tekstach polemicznych z IX w. (np. u al.-Dżahiza). 
$\mathrm{Z}$ drugiej strony także islam stopniowo zmodyfikował swoje arabskie oblicze na rzecz religii wielokulturowej. W zasadzie tylko pierwsza dynastia muzułmańska (Omajjadzi), reprezentowała kulturę arabsko-islamską. Kolejna dynastia panująca - Abbasydzi ${ }^{134}$ preferowała islam eklektyczny. Średniowieczni autorzy bizantyjscy coraz powszechniej nazywali Konstantynopol „nową Jerozolimą i miastem Boga"135.

Opis męczeństwa 60 chrześcijańskich żołnierzy z Gazy zachował się w dwóch wersjach łacińskich tłumaczeń (BHL 5672m i BHL 3053b). Po inwazji islamskiej to jeden $\mathrm{z}$ ostatnich akordów chrześcijańskiej przeszłości tego regionu. Chrześcijańskie dziedzictwo pogranicza palestyńsko-egipskiego stało się znaczące od IV w. mimo, że pogaństwo w Gazie było jeszcze dosyć silne. Geograficzna bliskość Egiptu sprawiała, że w tym graniczącym z Palestyną regionie bardzo szybko została rozniecona iskra życia monastycznego. W kolejnych stuleciach w Gazie dały o sobie znać idee monofizyckie i monoteleckie. Dyskusje dogmatyczne i konflikty pomiędzy zwalczającymi się frakcjami w sposób dramatyczny zakończył podbój arabski w VII w. Właśnie w tym czasie rozegrał się dramat męczeństwa żołnierzy chrześcijańskich. Odrzucili oni propozycję dowódcy zwycięskich muzułmanów, aby przyjąc ich religię. Chrześcijańscy jeńcy byli więzieni w różnych miejscach, a kaźni poddano ich w dwóch grupach. Po opisie egzekucji podane zostały imiona męczenników Chrystusa. Proste w formie opowiadania nakreśliły nie tylko losy niezłomnych chrześcijan, ale także kompleksową panoramę tamtego rejonu Bliskiego Wschodu w okresie podbojów islamskich. Opisy doświadczeń skazanych na śmierć to jednocześnie wskrzeszenie ducha chrześcijaństwa ery męczenników. Aktywnym uczestnikiem tamtych wydarzeń był patriarcha Jerozolimy Sofroniusz, występujący również pod imieniem Floriana. Łacińscy redaktorzy tekstu przydali mu także palmę męczeństwa. Stał się on przykładem dobrego pasterza, ofiarującego samego siebie za ciężko doświadczaną wspólnotę.

\section{HOLINESS IN THE TIME OF ISLAMIC CONQUEST. CHRISTIAN MARTYRS OF GAZA IN $7^{\mathrm{TH}}$ CENTURY}

\section{(Summary)}

The article focuses the story of the martyrdom of 60 Christian soldiers in Gaza who were executed for their refusal to convert to Islam during the Muslim invasion of Palestine. It is a final episode of varied Christian history of that region.

\footnotetext{
${ }^{134}$ Lata $750-1258$.

${ }^{135}$ Por. J. Darrouzès, Documents inédit d'ecclésiologie byzantine, Paris 1966, 199.
} 
Christian history of Gaza appears as complex and fascinating. In this region in the $4^{\text {th }}$ century paganism was still strong but the monastic life developed in the vicinity of Gaza. Literary sources annotated the anti-Chalcedonian resistance of monastic circles in the wake of the council of Chalcedon. Christian history of the Gaza region ended dramatically with the Arab conquest in the $7^{\text {th }}$ century. Just at that time a group of Christian soldiers refused the offer of the commander of the winners Muslims. The narrative of their martyrdom was preserved in a Latin translation of a Greek original. According to the text of the Passio, the Christian soldiers were executed in two groups: at Jerusalem and at Eleutheropolis. Bishop Sophronius of Jerusalem intervened in favor of these Martyrs and comforted them. He also gained the palm of martyrdom. The Passio in two different Latin recensions reveals a relatively neglected aspect in the history of the Holy Land during the period of heightened religious tension.

Key words: Gaza (Christianity in), martyrdom, Muslim invasion of Palestine, Sophronius of Jerusalem, Latin literature.

Słowa kluczowe: Gaza (chrześcijaństwo), męczeństwo, muzułmański podbój Palestyny, Sofroniusz z Jerozolimy, literatura łacińska.

\section{BIBLIOGRAFIA}

\section{Źródła}

Apophtegmata Patrum, PG 65, 71-440, tłum. M. Borkowska: Apoftegmaty Ojców Pustyni, t. 1: Gerontikon. Księga Starców, ŹM 4, Kraków - Tyniec 2004.

Eutychius Alexandrinus, Annales, ed. L. Cheikho, CSCO 50-51 (Scriptores Arabici 6-7), Louvain 1960-1962.

Gregorius Nyssenus, In Canticum canticorum homiliae XV, ed. H. Langerbeck, GNO VI, Leiden 1960, thum. M. Przyszychowska: Grzegorz z Nyssy, Homilie do Pieśni nad pieśniami, ŹMT 43, Kraków 2007.

Hieronymus, Vita Sancti Hilarionis, PL 23, 29-54, tłum. B. Degórski: Św. Hieronim, Żywot Hilariona, w: Św. Hieronim, Żywoty mnichów Pawła, Hilariona, Malchusa, ŹM 10, Kraków - Tyniec 1995.

Koran, thum. i kom. J. Bielawski, Warszawa 1986.

Legenda S. Floriani et sociorum, ed. H. Delehaye, w: tenże, Passio Sanctorum Sexaginta Martyrum, AnBol 23 (1904) 303-307.

Origenes, Contra Celsum VII-VIII, ed. M. Borret, SCh 150, Paris 1969, thum. S. Kalinkowski: Orygenes, Przeciw Celsusowi, Warszawa $1986^{2}$.

Origenes, Scholia in Canticum Canticorum, PG 17, 253-288.

Passio Sanctorum LX Martyrum, ed. H. Delehaye: Passio Sanctorum Sexaginta Martyrum, AnBol 23 (1904) 300-303.

Sophronius Hierosolymitanus, In Christi natalitia, ed. H. Usener, w: Weihnachtspredigt des Sophronios, „Rheinisches Museum für Philologie. Neue Folge” 41 (1886) 513-515.

Theophanes, Chronographia, PG 108, 55-1009. 


\section{Opracowania}

Abel F.M., Histoire de la Palestine depuis la conquète d'Alexandre jusqu'à l'invasion arabe, t. 1-2, Études bibliques 1, Paris 1952.

Alschech E., Islamic Law, Practice, and Legal Doctrine: Exempting the Poor from the Jizya under the Ayyubids (1171-1250), „Islamic Law and Society” 10 (2003) 348-375.

Ashrlanazi Y., Paganism in Gaza in the Fifth and Sixth Centuries, „Catedra” 60 (1991) 116-122.

Ashklanazi Y., Sophists and Priest in Late Antique Gaza According to Chloricius the Rhetor, w: Christian Gaza in Late Antiquity, ed. B. Bitton-Ashkelony - A. Kofsky, Jerusalem Studies in Religion and Culture 3, Leiden 2004, 195-208.

Bagatti B., Il cristianesimo ad Eleuteropoli, „Liber Annuus SBF” 22 (1972) 109-129.

Belayhe N., Pagan Festivals in Fourth-Century Gaza, w: Christian Gaza in Late Antiquity ed. B. Bitton-Ashkelony - A. Kofsky, Jerusalem Studies in Religion and Culture 3, Leiden 2004, 5-22.

Blair S., What Is the Date of the Dome of the Rock?, w: Bayt al-Maqdis, ed. J. Raby J. Johns, part 1, Oxford 1992, 59-87.

Bocheński F., Saraceni, w: Mały Stownik kultury świata arabskiego, red. J. Bielawski, Warszawa 1971, 455.

Chadwick H., John Moschus and His Friend Sophronius the Sophist, JTS 25 (1974) 41-74.

ChitTy D.J., A pustynia stała się miastem... Wprowadzenie do dziejów monastycyzmu w Egipcie i Palestynie pod panowaniem chrześcijańskim, tłum. T. Lubowiecka, red. nauk. T.M. Gronowski - R. Kosiński, ŹM 45, Kraków - Tyniec 2008.

Cohen M.R., Under Crescent and Cross: The Jews in the Middle Ages, Princeton 1994.

CoHen M.R., What was the Pact of 'Umar? A Literary-Historical Study, ,Jerusalem Studies in Arabic and Islam" 23 (1999) 100-157.

Constantelos D.J., Christian Hellenism. Essays and Studies in Continuity and Change, New Rochelle 1998.

Constantelos D.J., The Moslem Conquests of the Near East as Revealed in the Greek Sources in the Seventh and the Eight Centuries, ,Byzantion” 42 (1972) 325-357.

Delehaye H., Passio Sanctorum Sexaginta Martyrum, AnBol 23 (1904) 289-307.

Delehaye H., Les origines du culte des martyres, Bruxelles 1993.

Darrouzès J., Documents inédit d'ecclésiologie byzantine, Paris 1966.

Devos P., Pierre l'Ibère, quand vint-il à Jérusalem, AnBol 86 (1969) 337-350.

Donner F.M., The Early Islamic Conquests, Princeton 1981.

Downey G., Gaza: In the Early Sixth Century, Norman 1963.

Downey G., Paganism and Christianity in Procopius, ChH 18 (1949) 89-102.

FatTal A., Le statut légal des non-Musulmans en pays d'Islam, Beirut 1958.

Fleckenstein K.H. - L. Fleckenstein, Emmaus-Nicopolis. Ausgrabungen 2001-2005, Neckenmarkt -Wien - München 2010.

Friedmann Y., Tolerance and Coercion in Islam: Interfaith Relations in the Muslim Tradition, Cambridge 2003.

Gil M., A History of Palestine 634-1099, engl. trans. E. Broido, Cambridge - New York 1992.

Glucker C.A.M., The City of Gaza in the Roman and Byzantine Periods, BAR International Series 325, Oxford 1987.

Grabar O., The Shape of the Holy. Early Islamic Jerusalem, Princeton 1996.

Grego I., Eudossia imperatrice, primadonna e santa, „Studia Orientalia Christiana - Collectanea" 25 (1992) 335-360. 
Grego I., Giovanni II, vescovo di Gerusalemme: le controversie origenista e pelagiana, „Studia Orientalia Christiana - Collectanea” 22 (1989) 97-126.

Guillou A., La Prise de Gaza par les Arabes au VII siècle, „Bulletin de Correspondance Hellenique" 81 (1957) 396-404.

Herràn Alonso E., La configuración literaria del tópico del „, miles Christi” entre l'Edad Media y el Renacimiento, w: Actes del X Congrés Internacional de l'Associación Hispànica de Literatura Medieval (Alacant, 16-20 setembre 2003), ed. R. Alemany J.L. Martosi - J.M. Manzanaro, Alacant 2005, 879-893.

Hombergen D., Barsanuphius and John of Gaza and the Origenist Controversy, w: Christian Gaza in Late Antiquity, ed. B. Bitton-Ashkelony - A. Kofsky, Jerusalem Studies in Religion and Culture 3, Leiden 2004, 173-182.

Hunt E.D., Holy Land Pilgrimage in the Later Roman Empire AD 312-460, Oxford 1982.

HuXLEy G., The Sixty Martyrs of Jerusalem, GRBS 18 (1977) 369-374.

Issa A.O., Les minorites chrétiennes de Palestine à travers les siècles, Jerusalem 1976.

KAEGI W.E., Byzantium and the Early Islamic Conquests, Cambridge 1992.

Karczewska H., Funkcja wieńców w tradycji antycznej, „Seminare” 26 (2009) 341-350.

Kaswalder P.A., Onomastica biblica. Fonti scritte e ricerca archeologica, Collectio Minor 40, Jerusalem 2002, 189.

Kofsky A., What Happened to the Monophysite Monasticism of Gaza?, w: Christian Gaza in Late Antiquity, ed. B. Bitton-Ashkelony - A. Kofsky, Jerusalem Studies in Religion and Culture 3, Leiden 2004, 184-194.

Kopeć E., Koran a Biblia, RBL 3 (1952) 263-272.

Lamoreaux J.C., Early Eastern Christian Responses to Islam, w: Medieval Christian Perceptions of Islam. A Book of Essays, ed. J.V. Tolan, New York - London 1996, 3-31.

Lanzoni F., S. Petronio di Bologna nella storia e nella leggenda, Roma 1907.

Le christianisme antique et son contexte religieux, éd. M. Simon, Tübingen 1981.

LEDER S., The literary use of the Khabar: a basic form of historical writing, w: The Byzantine and Early Islamic Near East, t. 1: Problems in the Literary Source Materials, ed. A. Cameron - L.I. Conrad, Studies in Late Antiquity and Early Islam 1, Princeton 1992, 277-315.

Meyer M.A., History of the City of Gaza. From the Earliest Times to the Present Day, Columbia University Oriental Studies 5, New York 1907.

Muelhaeusler M., Problems of Differentiation Between Muslims and Non-Muslims: Re-Reading the ,Ordinances of 'Umar' (al-shurūt. al- 'umariyya), w: Muslims and Others in Early Islamic Society, ed. R. Hoyland, Aldershot 2004, 103-124.

Neri D., Il Santo Sepolcro riprodotto in Occidente, Jerusalem 1971.

Noтн A., Abgrenzungsprobleme zwischen Muslimen und Nicht-Muslimen: Die 'Bedingungen 'Umars (aš-šurūt al- 'umariyya)' unter einem anderen Aspekt gelesen, ,Jerusalem Studies in Arabic and Islam" 9 (1987) 290-315.

Pargoire J., Les LX Soldats Martyrs de Gaza, EO 8 (1905) 40-43.

Perrone L., La chiesa di Palestina e le controversie cristologiche, Brescia 1980.

Perrone L., The Necessity of Advice: Spiritual Direction as a School of Christianity in the Correspondence of Barsanuphius and John of Gaza, w: Christian Gaza in Late Antiquity, ed. B. Bitton-Ashkelony - A. Kofsky, Jerusalem Studies in Religion and Culture 3, Leiden 2004, 131-150.

Piccirillo M., La Palestina cristiana. I-VII secolo, Bologna 2008.

PogGi V., Fede e cultura nel cristianesimo e nell'islam primitivi, w: Il mondo islamico tra interazione e acculturazione, ed. A. Bausani - B. Scarcia Amoretti, Roma 1981, 99-116. 
Regnault L., Moines et laïcs dans la région de Gaza au VIe siècle, w: Christian Gaza in Late Antiquity, ed. B. Bitton-Ashkelony - A. Kofsky, Jerusalem Studies in Religion and Culture 3, Leiden 2004, 165-172.

Rızzi E., Santo Stefano Rotondo a Roma, w: Rotonde d'Italia. Analisi tipologica della pianta centrale, ed. V. Volta, Milano 2008, 150-154.

Robinson Ch.F., Neck-Sealing in Early Islam, ,Journal of the Economic and Social History of the Orient" 48 (2005) 401-441.

SAmir K., Religion et culture en Proche-Orient arabe, POC 39 (1989) 251-309.

Schönborn von Ch., Sophrone de Jérusalem. Vie Monastique et Confession Dogmatique, Théologie Historique 20, Paris 1972.

Segni Di L., The Territory of Gaza: Notes of Historical Geography, w: Christian Gaza in Late Antiquity, ed. B. Bitton-Ashkelony - A. Kofsky, Jerusalem Studies in Religion and Culture 3, Leiden 2004, 41-60.

Southern R.W., Western views of Islam in the Middle Ages, Cambrige 1962.

StÄGer R., Chrétiens d'Arabie affrontés à l'Islam. Les deux „pactes” de Najran (632 et 897), POC 48 (1998) 249-293.

Starowieyski M., Piotr Iberyjski, SWPW 185-186.

Steppa J.E., Heresy and Orthodoxy: The Anti-Chalcedonian Hagiography of John Rufus, w: Christian Gaza in Late Antiquity, ed. B. Bitton-Ashkelony - A. Kofsky, Jerusalem Studies in Religion and Culture 3, Leiden 2004, 89-106.

Strus A., L'origine de l'apocryphe grec de la Passion de S. Étienne: à propos d'un texte de deux manuscrits récemment publiés, EL 112 (1998) 18-57.

Strus A., La passione di Santo Stefano in due manoscritti greci, „Salesianum” 58 (1996) nr 1, 21-61.

Szczur P., Piotr Iberyjczyk, EK XV 677.

Usner H., Weihnachtspredigt des Sophronios, „Rheinisches Museum für Philologie. Neue Folge" 41 (1886) 500-516.

Valognes J.-P., Vie et mort des chrètiens d'Orient. Dés origines à nos jours, Paris 1995.

Verghese P., The Monothelite Controversy - Historical Survey, GOTR 13 (1968) 196-211.

Woods D., The 60 Martyrs of Gaza and the Martyrdom of Bishop Sophronius of Jerusalem, „ARAM - Society for Syro-Mesopotamian Studies Periodical” 15 (2003) 129-150. 
